\title{
Deep water chondrichthyans from the Early Miocene of the Vienna Basin (Central Paratethys, Slovakia)
}

Charlie J. Underwood and Jan Schlogl

Acta Palaeontologica Polonica 58 (3), 2012: 487-509 doi: http://dx.doi.org/10.4202/app.2011.0101

Sampling of latest Burdigalian (Miocene) silty clays from the Malé Karpaty Mountains in the Slovakia revealed a deep-water, low diversity shark fauna. The fauna is dominated by teeth of very small squaliform sharks, including two new species, Eosqualiolus skrovinai sp. nov. and Paraetmopterus horvathi sp. nov. The generic composition of the squaliform fauna is more similar to that known from the Eocene than that of today, suggesting a post-early Miocene faunal turnover within this clade, at least locally. Nectobenthic, non squaliform sharks are rare, but include the new sawshark species Pristiophorus striatus sp. nov., while minute teeth of an enigmatic taxon described here as Nanocetorhinus tuberculatus gen. et sp. nov. probably indicate the presence of a previously unrecorded planktivore. The unusual composition of the fauna, with the complete absence of taxa known to be of medium to large size, suggests an unusual, and probably very stressed, palaeoenvironment.

Key words: Squaliformes, Dalatidae, Etmopteridae, Pristiophorus, sharks, Miocene, Slovakia, Paratethys.

Charles J. Underwood [c.underwood@bbk.ac.uk], Department of earth and Planetary Science, Birkbeck, Malet Street, London WC1E 7HX, UK; Jan Schlog1 [schlogl@nic.fns.uniba.sk], Department of Geology and Palaeontology, Faculty of Natural Sciences, Comenius University, Mlynská dolina G1, Bratislava 842 15, Slovakia.

This is an open-access article distributed under the terms of the Creative Commons Attribution License (for details please see creativecommons.org), which permits unrestricted use, distribution, and reproduction in any medium, provided the original author and source are credited. 
Fof Full text $(1,252.9 \mathrm{kB})$ 